MATEC Web of Conferences 25, 02002

(2015)

DOI: $10.1051 /$ matecconf/ 20152502002

(c) Owned by the authors, published by EDP Sciences, 2015

\title{
A Green Method for Synthesis of 7H-thiazolo[3,2-b][1,2, 4]-triazin- 7-one Derivatives as AChE Inhibitors
}

\author{
Sijie Liu*, Baohua Zhang, Pengfei Jia, Nan Niu, Jingyu He \& Lanxiang Shi \\ College of Chemical Engineering, Shijiazhuang University, Shijiazhuang, Hebei, China
}

ABSTRACT: The authors study an efficient and green approach for the synthesis of $7 \mathrm{H}$-thiazolo [3, 2-b][1,2,4]triazin-7-one derivatives as AChE inhibitors. The 7H-thiazolo[3,2-b][1,2,4]triazin-7-ones were designed by molecular docking, and readily prepared via a one-pot reaction in morpholine hydrosulfate ([Hnhm]HSO4) lonic liquid as the catalyst and solvent. The study of AChE inhibitory activity was carried out through using the Ellman colorimetric assay. The 7H-thiazolo[3,2-b][1,2,4]triazin-7-ones had been successfully synthesized by green catalyst. Most of the target compounds exhibited more than $50 \%$ inhibition at $10 \mu \mathrm{M}$.

Keywords: 7H-thiazolo[3,2-b][1,2,4]triazin-7-ones; lonic liquid; AChE inhibitor; synthesize

\section{INTRODUCTION}

The green chemistry movement began more than two decades ago. Specifically, the challenge in chemistry is to develop new products, processes, and services that achieve the societal, economic, and environmental benefits that are required now and tomorrow, and the need for alternative solvents for reactions has been one of the major issues we have faced ${ }^{[1]}$. Owing to their unique properties such as good solvating ability, negligible vapor pressure, variable polarity, nonflammability, and recyclability, ionic liquids have been widely used as catalysts and reaction media ${ }^{[2]}$.

The global population has reached seven billion on Monday, October 31, 2011, accompanied by an aging society ${ }^{[3]}$. What will life in an aging society be maybe dramatically increased the age-related diseases. Alzheimer's disease (AD) is the most common single cause of dementia in the aging society, and it can be diagnosed in people over 65 years of age though the less-prevalent early-onset Alzheimer's can occur much earlier. In 2006, there were 26.6 million sufferers worldwide. Alzheimer's is predicted to affect 1 in 85 people globally by $2050^{[4]}$.

In our previous work, 7H-thiazolo[3,2-b]- 1,2,4triazin-7-one derivatives were designed and synthesized, which exhibited inhibitory activity against acetylcholinesterase (AChE), and the molecular docking exhibited 7H-thiazolo [3,2-b]-1,2,4-triazin-7-one derivatives interacted with the catalytic active site (CAS) and the peripheral anionic site (PAS) of $\mathrm{AChE}^{[5-7]}$. $\mathrm{AChE}$ is a hydrolase that catalyzes the hydrolysis of neurotransmitter acetylcholine and it is presented in the most prominent constituents of central cholinergic pathways. AChE plays a crucial role in central and peripheral nervous systems ${ }^{[8]}$. Reduction in the activity of the cholinergic neurons is a well-known feature of $\mathrm{AD}$. AChE inhibitors are employed to reduce the rate at which acetylcholine (ACh) is broken down, thereby increasing the concentration of $\mathrm{ACh}$ in the brain and combating the loss of $\mathrm{ACh}$ which is caused by the death of cholinergic neurons ${ }^{[9]}$.

In continuation of our interest in developing new environmentally friendly methods and studying the the structure-AChE inhibitory activity relationships of 7H-thiazolo[3,2-b] -1,2,4-triazin-7-one derivatives, we utilized the acidic ionic liquid Morpholine hydrosulfate $\left([\mathrm{Hnhm}] \mathrm{HSO}_{4}\right)$ as catalyst and solvent for the synthesis of a new series of 7H-thiazolo[3,2-b][1,2,4]triazin-7-one derivatives. The inhibitory activity against $\mathrm{AChE}$ was evaluated.

\section{RESULTS AND DISCUSSION}

\subsection{Chemistry}

In the course of this study, we developed green chemistry by one-pot syntheses of target molecules in the absence of $[\mathrm{Hnhm}] \mathrm{HSO}_{4}$. The reaction scheme was shown in Figure 1. Various substituted arylpyruvic acids $\mathbf{1}$, thiosemicarbazide $\mathbf{2}$, and $\alpha$-bromo acetophenone 3 are converted into $7 \mathrm{H}$ - thiazolo[3,2-b]-1,2,4triazin-7-ones 4 in the presence of $[\mathrm{Hnhm}] \mathrm{HSO}_{4}$.

The effects of synthetic temperature, catalyst, and reaction time on the product yield were discussed. The reaction of 4-chlorophenylpyruvicacid, thiosemicarbazide, and $\alpha$-bromoacetophenone was selected as a model reaction to optimize the reaction temperature for the synthesis of $\mathbf{4 a}$ in $[\mathrm{Hnhm}] \mathrm{HSO}_{4}$ (1 equiv.). The results are summarized in Table 1 . Based on the experimental results, with temperature increasing, the reaction rate was accelerated and the yield was increased. The highest yield was obtained at $80{ }^{\circ} \mathrm{C}$. By repeated tests, a proper amount of catalyst loading for the model reaction is fixed. The amount of [Hnhm $] \mathrm{HSO}_{4}$ was increased from 0.1 to 0.9 equivalents. The results are summarized in Table 2. What's

This is an Open Access article distributed under the terms of the Creative Commons Attribution License 4.0, which permits unrestricted use, distribution, and reproduction in any medium, provided the original work is properly cited. 


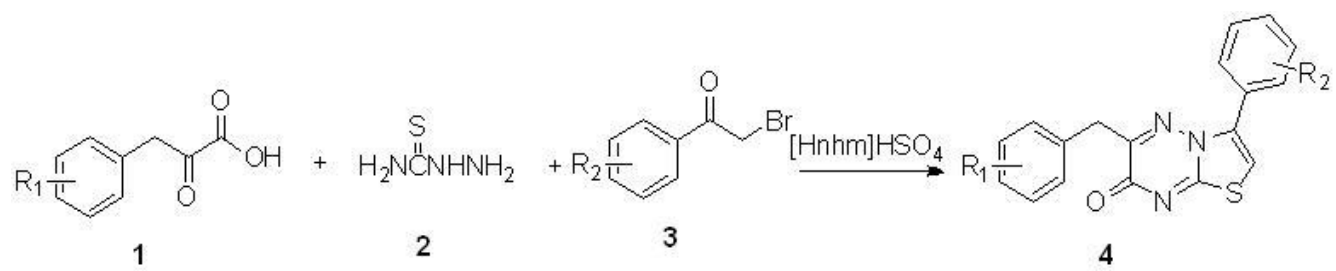

Figure 1. Synthetic route of 7H-thiazolo[3,2-b]-1,2,4 -triazin-7-ones

more, the results also indicated that the yield of $\mathbf{4 a}$ may not be obviously increased with the increasing amount of $[\mathrm{Hnhm}] \mathrm{HSO}_{4}$ from 0.5 to 0.9 equiv. Thus, we chose 0.5 equiv. as the optimal amount of catalyst for further experiments.

Table 1. Effects of the reaction temperature on the synthesis of $\mathbf{4 a}$ in $[\mathrm{Hnhm}] \mathrm{HSO}_{4}$

\begin{tabular}{llll}
\hline No. & Temp $/{ }^{\circ} \mathrm{C}$ & Time $/ \mathrm{h}$ & Yield $/ \%$ \\
\hline 1 & 20 & 3 & 32 \\
2 & 40 & 3 & 45 \\
3 & 60 & 3 & 78 \\
4 & 80 & 3 & 93 \\
5 & 100 & 3 & 85 \\
\hline
\end{tabular}

Table 2. Effects of the amount of $[\mathrm{Hnhm}] \mathrm{HSO}_{4}$ on the synthesis of $4 \mathbf{a}$ at $80{ }^{\circ} \mathrm{C}$

\begin{tabular}{llll}
\hline No. & {$[\mathrm{Hnhm}] \mathrm{HSO}_{4} /$ equiv. } & Time $/ \mathrm{h}$ & $\mathrm{Yield} / \%$ \\
\hline 1 & 0.1 & 3 & 31 \\
2 & 0.3 & 3 & 68 \\
3 & 0.5 & 3 & 91 \\
4 & 0.7 & 3 & 92 \\
5 & 0.9 & 3 & 93 \\
\hline
\end{tabular}

The recyclability of the catalyst was investigated through using the same reaction and scale. Upon the completion of the reaction, the product was readily isolated by filtration, washed with water, and dried under vacuum without further separation, whereas the filtrate containing $[\mathrm{Hnhm}] \mathrm{HSO}_{4}$ was dried to remove water at $60{ }^{\circ} \mathrm{C}$ under vacuum. The recovered ionic liquid was reused in the subsequent reactions. As shown in Table 3 , for the preparation of $\mathbf{4 a}$, the ionic liquid $[\mathrm{Hnmp}] \mathrm{HSO}_{4}$ could be recycled three times without considerable decrease of activity.

$\underline{\text { Table 3. Recycling performance of } 0.5 \text { equiv. [Hnhm] } \mathrm{HSO}_{4}}$

\begin{tabular}{llll}
\hline No. & Temp $/{ }^{\circ} \mathrm{C}$ & Time $/ \mathrm{h}$ & Yield $/ \%$ \\
\hline 1 & 80 & 3 & 91 \\
2 & 80 & 3 & 87 \\
3 & 80 & 3 & 85 \\
4 & 80 & 3 & 83 \\
\hline
\end{tabular}

Under this optimal condition, 7H-thiazolo[3,2-b] $[1,2,4]$ triazin-7-one derivatives was synthesized. As indicated in Table 4, the reaction efficiently proceeds with all of them.
Table 4. Synthesis of 7H-thiazolo[3,2-b][1,2,4] triazin-7-ones in 0.5 equiv. [Hnhm] $\mathrm{HSO}_{4}$ at $80{ }^{\circ} \mathrm{C}$

\begin{tabular}{lllll}
\hline No. & $\mathrm{R}_{1}$ & $\mathrm{R}_{2}$ & Product & Yield/\% \\
\hline 1 & $4-\mathrm{Cl}$ & $4-\mathrm{Cl}$ & $4 \mathrm{a}$ & 91 \\
2 & $4-\mathrm{OCH}_{3}$ & $2-\mathrm{OH}$ & $4 \mathrm{~b}$ & 90 \\
3 & $3-\mathrm{OCH}_{3}$ & $4-\mathrm{Br}$ & $4 \mathrm{c}$ & 92 \\
4 & $3-\mathrm{OCH}_{3}$ & $4-\mathrm{Cl}$ & $4 \mathrm{~d}$ & 92 \\
5 & $3-\mathrm{OCH}_{3}$ & $2-\mathrm{OH}$ & $4 \mathrm{e}$ & 91 \\
6 & $4-\mathrm{OH}$ & $4-\mathrm{CH}$ & $4 \mathrm{f}$ & 90 \\
7 & $4-\mathrm{OCH}_{3}$ & $4-\mathrm{OH}$ & $4 \mathrm{~g}$ & 89 \\
8 & $4-\mathrm{OCH}_{3}$ & $4-\mathrm{OCH}_{3}$ & $4 \mathrm{~h}$ & 90 \\
\hline
\end{tabular}

\subsection{Inhibition of AChE}

Inhibitory activities of target compounds on AChE were determined in comparison with the huperzine-A and the results data were reported in Table 5. All compounds are properly showed to good hAChE inhibitory activities with inhibition values ranging from $40.58 \%$ to $64.36 \%$. 4b exhibited the best inhibitory activity to AChE with the mean inhibition value of $64.36 \%$. The compounds $4 \mathrm{~b}, 4 \mathrm{e}$ and $4 \mathrm{f}$ showed better activity, and it is probably due to the presence of hydroxy group, which would be able to form hydrogen bond with AChE receptor.

Table 5. Inhibition of human AChE Activities by the targets at $10 \mu \mathrm{M}(\mathrm{n}=2)$

\begin{tabular}{llll}
\hline No. & Inhibition $(100 \%)$ & No. & Inhibition $(100 \%)$ \\
\hline $4 \mathrm{a}$ & 59.75 & $4 \mathrm{e}$ & 63.32 \\
$4 \mathrm{~b}$ & 64.36 & $4 \mathrm{f}$ & 62.98 \\
$4 \mathrm{c}$ & 56.96 & $4 \mathrm{~g}$ & 62.43 \\
$4 \mathrm{~d}$ & 40.58 & $4 \mathrm{~h}$ & 48.56 \\
\multicolumn{2}{l}{ Huperzine-A } & & 100 \\
\hline
\end{tabular}

\subsection{Docking studies}

Solution of the 3D structure of Torpedo californica acetylcholinesterase in 1991 opened up new horizons in research on an enzyme that had already been the subject of intensive investigation ${ }^{[10] .}$ One of the striking structural features of the AChE revealed from the $\mathrm{X}$-ray analysis is the presence of a narrow, long, hydrophobic gorge which is approximately $20 \AA$ deep ${ }^{[11]}$. The AChE aromatic gorge includes the following loci [12]: At the bottom of the gorge a catalytic triad (Ser200, His440 and Glu327) lies in catalytic active 
site (CAS). The second binding is referred to as the peripheral anionic site (PAS), including Tyr70, Asp72, Tyr121, Glu278, Trp279 and Tyr334; it is known to be located at the gorge mouth around $18 \AA$ away from the active site. Furthermore, in the middle of the gorge, Trp84, Tyr130, Phe330 and Tyr442 form an anionic binding site, a binding site for the quaternary nitrogen of their substrates and some ligands. The crystal structure of human AChE had been reported in $2000^{[13]}$. Comparison of the three-dimensional structures of TcAChE (1EVE) and hAChE (1B41) revealed a high degree of similarity, especially with regard to the active sites. The most significant difference between the active sites of TcAChE and hAChE is that the Phe 330 of TcAChE was replaced with a Tyr337 of $\mathrm{hAChE}$. Another difference is that the sequence number of some protein residues. For example, Ser200 of TcAChE was replaced by Ser203 of hAChE. The result was shown in Table 6:

Table 6. Differences in the protein residues of TcAChE and hAChE

\begin{tabular}{lll}
\hline Active Site & TcAChE & hAChE \\
\hline catalytic active site (CAS) & Ser200 & Ser203 \\
& Glu327 & Glu334 \\
& His440 & His447 \\
anionic binding site & Trp84 & Trp86 \\
& Tyr130 & Tyr133 \\
& Phe330 & Tyr337 \\
& Tyr442 & Tyr449 \\
peripheral anionic site (PAS) & Tyr70 & Tyr72 \\
& Asp72 & Asp74 \\
& Tyr121 & Tyr124 \\
& Glu278 & Glu285 \\
& Trp279 & Trp286 \\
& Tyr334 & Tyr341 \\
\hline
\end{tabular}

To investigate the binding mode of the series of 7H-thiazolo[3,2-b]-1,2,4-triazin-7-one derivatives, docking simulations were performed with AUTODOCK 4 software. The model of the receptor was based on the crystal structure of hAChE complex with donepezil (PDB ID: 4EY7). The cocrystal natural substrate was taken out of the active site and docked again. The top three docking configurations were taken into consideration to validate the results, and the RMSD was calculated for each configuration in comparison with the co-crystallized ligand, donepezil. The acceptable results indicated that the docked configurations have similar binding positions and orientations within the binding site and they are similar to the co-crystal structure, which illustrates the fact that the used docking protocols could successfully generate the crystal donepezil-AChE complex precisely. The proposed binding model of donepezil with the key residues in the gorge site is shown in Figure 2. The binding model suggests that donepezil is bound near the bottom of the gorge, and it shows parallel $\pi-\pi$ stacking against the six-membered ring of Trp86 in- dole, while the indanone ring stacks against Trp286 in the PAS. The piperidinic nitrogen of the ligand contains a positive charge and complexes by cation- $\pi$ interaction with the phenyl group of Tyr341 of the enzymatic cavity. And Donepezil interacts with key amino acid residues such as Ser203, His447 at the CAS and Tyr72, Asp74, and Trp286 at PAS.

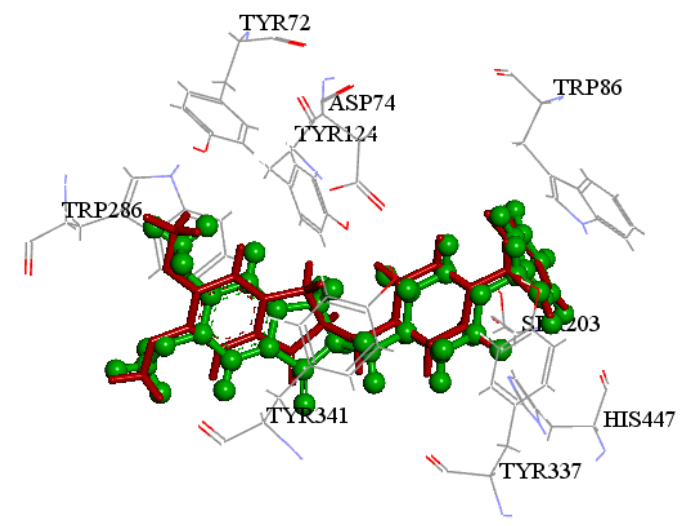

Figure 2. Binding orientation of redocked co-crystal donepezil with ball and stick (green) and original donepezil with stick (red)

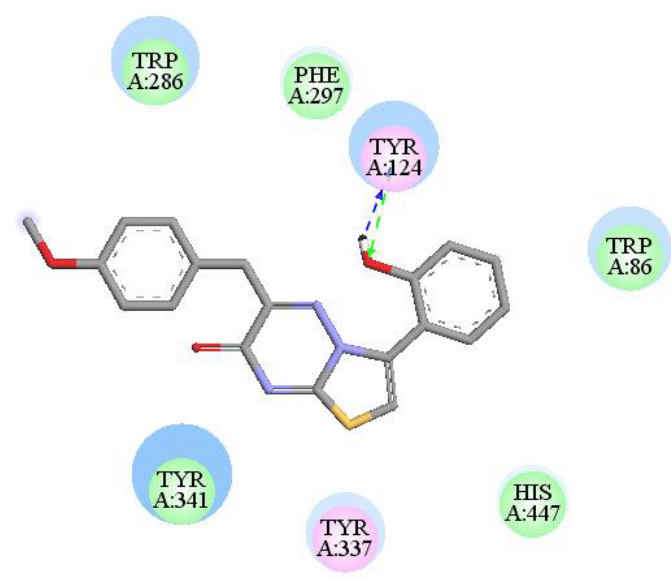

Figure 3. Docking model of compound $4 \mathrm{~b}$ in the active sites of hAChE

The docking simulations reveal all target compounds exhibited multiple binding modes with the human AChE. For example, the compound $\mathbf{4 b}$ occupies the peripheral anionic site, the mid interaction site and the catalytic active site through hydrophobic interactions with Trp86, Trp286, Tyr341 and His447 (see Figure 3). The compound $4 \mathbf{e}$ formed hydrophobic interactions with Tyr72, Asp74, Tyr124, Trp286, Tyr341, Tyr337 and His447. The thiazolo[3,2-b]1,2,4-triazin-7-one ring can establish a $\pi$ - $\pi$ interaction with the aromatic ring of Trp86 (see Figure 4). For 


\section{MATEC Web of Conferences}

another example, the phenyl group of the compound 4f can establish a $\pi$ - $\pi$ interaction with the aromatic ring of Tyr341, and at the same time, it forms hydrophobic interactions with Asp74, Trp86, Trp286 and Tyr337. The thiazolo[3,2-b]-1,2,4-triazin ring can form hydrophobic interaction with His447 in CAS (see Figure 5). Additionally significant H-bond interactions were also observed among the $-\mathrm{OH}$ group of compound 4b with Tyr124, the -OH group of compound $4 \mathrm{e}$ with Ser203 and the -OH group of compound $4 \mathbf{f}$ with Tyr72, which might be the reason for their increased potency.

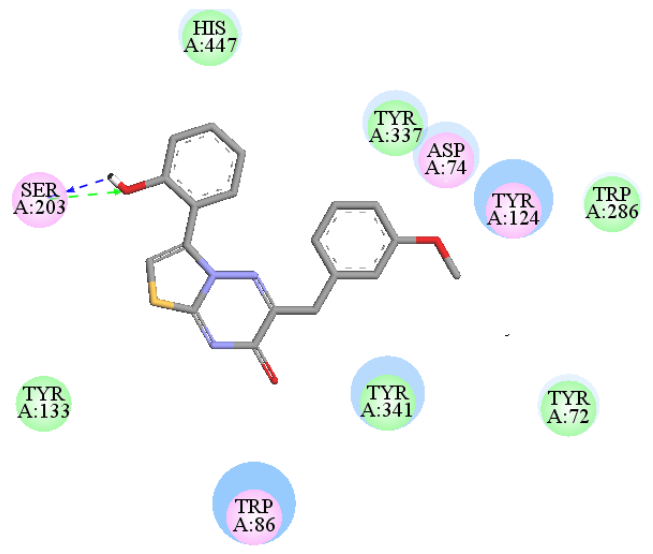

Figure 4. Docking model of compound $4 \mathrm{e}$ in the active sites of hAChE

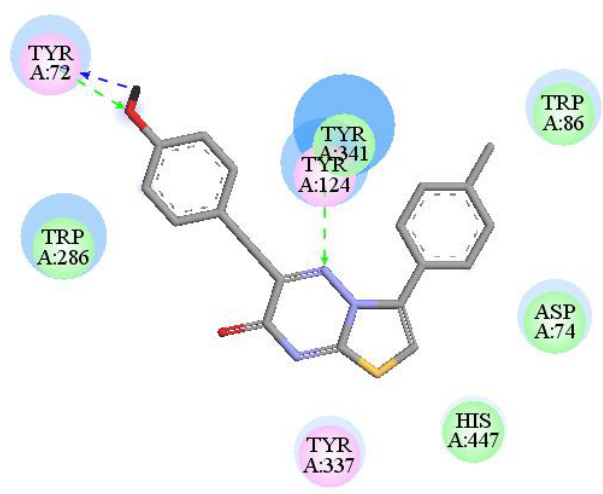

Figure 5. Docking model of compound $4 \mathrm{f}$ in the active sites of hAChE

\section{EXPERIMENTAL SECTION}

\subsection{Chemistry}

Reagents and solvents were purchased from common commercial suppliers and were used without further purification. All melting points were taken in open capillary tubes and are uncorrected. Nuclear magnetic resonance spectra were recorded in $\mathrm{CDCl}_{3}$ or DMSO solutions through using Bruker $300 \mathrm{MHz}$ spectrometers or $600 \mathrm{MHz}$ spectrometers. The mass spectra (MS) were obtained by electronic impact (EI) at $70 \mathrm{eV}$ in an Agilent spectrometer (with direct insertion probe) or by electrospray (ESI) in a Waters spectrometer. The IR spectra were obtained through using a PerkineElmer 298 spectrometer (PerkineElmer, Norwalk, CT, USA).

3.2 General procedure for synthesis of various substituted arylpyruvic acids 1

A mixture of aromatic aldehyde (100 mmol), $\mathrm{N}$-acylglycine $(10.7 \mathrm{~g}, 120 \mathrm{mmol})$ and sodium acetate $(51 \mathrm{~g}, 500 \mathrm{mmol})$ were mixed and heated at $120^{\circ} \mathrm{C}$ for $7 \mathrm{~h}$ in acetic anhydride. After completion of the reaction, the resulting solution was kept in refrigerator overnight to obtain a solidified mass which was triturated with cold water and ethanol. The resulting yellow crystals were collected and dried to give 4-(arylmethylene)-2-methyl-5(4H) -oxazolone.

4-(Arylmethylene)-2-methyl-5(4H)-oxazolone(10.8 $5 \mathrm{~g}, 50 \mathrm{mmol})$, acetone $(85 \mathrm{~mL})$, and $\mathrm{H}_{2} \mathrm{O}(70 \mathrm{~mL})$ were refluxed for $10 \mathrm{~h}$. The solvent was evaporated to give 2-acetamido-3-arylacrylic acids as a residual solid.

2-Acetamido-3-arylacrylic acids $(10 \mathrm{mmol})$ and 1 $\mathrm{mol} / \mathrm{L} \mathrm{HCl}$ aqueous solution $(60 \mathrm{~mL})$ were refluxed for $7 \mathrm{~h}$. After that the resulting mixture was allowed to cool to room temperature. And the resulting precipitate was collected by filtration. The filtrate was extracted with ethyl acetate $(3 \times 20 \mathrm{~mL})$. The organic extract was evaporated to give arylpyruvic acid which was combined with the filtered precipitate. The aryl pyruvic acid was dried under vacuum and was recrystallized form ethanol.

\subsection{General procedure for synthesis of} 7H-thiazolo[3,2-b][1,2,4]triazin-7-ones $(4 a-4 h)$

Arylpyruvic acid $1(1 \mathrm{mmol})$ and thiosemicarbazide (2, $1.1 \mathrm{mmol}$ ) were mixed together in the presence of $[\mathrm{Hnhm}] \mathrm{HSO} 4$, then they were stired at $80^{\circ} \mathrm{C}$. An hour later, $\alpha$-bromoacetophenone $3(1.1 \mathrm{mmol})$ were added. Upon the completion of the reaction, the reaction mixture was poured into water and the precipitate of 7H-thiazolo-[3,2-b][1,2,4]triazin-7-one 4 was filtered, washed, and crystallized from ethanol. The residue solution containing [Hnhm]HSO4 was reused for subsequent reactions.

\subsubsection{6-(4-chlorobenzyl)-3-(4-chlorophenyl)-7H-thia zolo[3,2-b]-1,2,4-triazin-7-one (4a)}

Yellow crystal; mp: $230-232^{\circ} \mathrm{C} ;{ }^{1} \mathrm{H}-\mathrm{NMR}(600 \mathrm{MHz}$ DMSO-d6): $\delta 7.61(2 \mathrm{H}, \mathrm{d}, J=9.0 \mathrm{~Hz}), 7.58(1 \mathrm{H}, \mathrm{s})$, $7.48(2 \mathrm{H}, \mathrm{d}, J=8.4 \mathrm{~Hz}), 7.37(2 \mathrm{H}, \mathrm{d}, J=9.0 \mathrm{~Hz}), 7.31$ $(2 \mathrm{H}, \mathrm{d}, J=8.4 \mathrm{~Hz}), 3.98(2 \mathrm{H}, \mathrm{s}) ;$ ESI-MS $(\mathrm{m} / \mathrm{z}): 387.9$ $(\mathrm{M}+\mathrm{H})^{+}, 798.6(2 \mathrm{M}+\mathrm{Na})^{+}$; IR $(\mathrm{KBr}): v 3104,1636$, $1576,1482,1402,1383,1359,1322,1188,1118$, 
1093, 1043, 1014, 878, 808, $755 \mathrm{~cm}^{-1}$.

3.3.2 6-(4-methoxybenzyl)-3-(4-hydroxyphenyl)-7H-t hiazolo[3,2-b]-1,2,4-triazin-7-one (4b)

White crystal; mp: $218-219^{\circ} \mathrm{C}$; ${ }^{1} \mathrm{H}-\mathrm{NMR}(300 \mathrm{MHz}$, DMSO-d6): $\delta 9.99(1 \mathrm{H}, \mathrm{s}), 7.37(1 \mathrm{H}, \mathrm{s}), 7.32-7.58$ $(2 \mathrm{H}, \mathrm{m}), 7.18(2 \mathrm{H}, \mathrm{d}, J=8.7 \mathrm{~Hz}), 6.99(1 \mathrm{H}, \mathrm{d}), 6.89$ $(1 \mathrm{H}, \mathrm{t}), 6.81(2 \mathrm{H}, \mathrm{d}, J=8.7 \mathrm{~Hz}), 3.80(2 \mathrm{H}, \mathrm{s}), 3.72(3 \mathrm{H}$, s); EI-MS (m/z): 51, 63, 77, 89, 104, 121, 132, 147, $159,174,192,193,218,231,282,350,365(\mathrm{M})^{+}$; IR (KBr): v 3102, 2965, 1663, 1621, 1571, 1513, 1486 , $1384,1294,1267,1243,1180,1127,1107,1047$, $1025,943,921,879,842,803,773 \mathrm{~cm}^{-1}$.

\subsubsection{6-(3-methoxybenzyl)-3-(4-bromophenyl)-7H-thi} azolo [3,2-b]-1,2,4-triazin-7-one (4c)

Yellow crystal; mp: $201-203{ }^{\circ} \mathrm{C} ;{ }^{1} \mathrm{H}-\mathrm{NMR}(600 \mathrm{MHz}$, DMSO-d6): $\delta$ 7.59-7.63 $(5 \mathrm{H}, \mathrm{m}), 7.22(1 \mathrm{H}, \mathrm{t}), 6.87$ $(1 \mathrm{H}, \mathrm{s}), 6.85(1 \mathrm{H}, \mathrm{d}), 6.82(1 \mathrm{H}, \mathrm{d}), 6.77(1 \mathrm{H}, \mathrm{s}), 3.94$ $(2 \mathrm{H}, \mathrm{s}), 3.71(3 \mathrm{H}, \mathrm{s}) ;$ ESI-MS $(\mathrm{m} / \mathrm{z}): 428.1\left([\mathrm{M}+\mathrm{H}]^{+}\right)$, $450.3\left([\mathrm{M}+\mathrm{Na}]^{+}\right) ;$IR $(\mathrm{KBr}): v$ 3101, 2950, 1635, $1576,1480,1384,1322,1296,1259,1152,1113$, $1047,1007,818,784,754 \mathrm{~cm}^{-1}$.

\subsubsection{6-(3-methoxybenzyl)-3-(4-chlorophenyl)-7H-thi azolo[3,2-b]-1,2,4-triazin-7-one (4d)}

Yellow crystal; mp: $213-214^{\circ} \mathrm{C} ;{ }^{1} \mathrm{H}-\mathrm{NMR}(300 \mathrm{MHz}$, $\mathrm{CDCl} 3): \delta 7.48(2 \mathrm{H}, \mathrm{d}, J=8.6 \mathrm{~Hz}), 7.40(2 \mathrm{H}, \mathrm{d}, J=$ $8.6 \mathrm{~Hz}), 7.22(1 \mathrm{H}, \mathrm{t}), 6.90(2 \mathrm{H}, \mathrm{d}), 6.82(2 \mathrm{H}, \mathrm{d}), 4.10$ $(2 \mathrm{H}, \mathrm{s}), 3.77(3 \mathrm{H}, \mathrm{s})$; ESI-MS(m/z): $284.2\left([\mathrm{M}+\mathrm{H}]^{+}\right)$; IR (KBr): v 3103, 2932, 1636, 1577, 1482, 1403, 1384, $1297,1258,1154,1115,1090,1050,1010,846,819$, $785,767,756 \mathrm{~cm}^{-1}$.

\subsubsection{6-(3-methoxybenzyl)-3-(4-hydroxyphenyl)-7H-t} hiazolo[3,2-b]-1,2,4-triazin-7-one (4e)

Yellow crystal; mp: $200-203{ }^{\circ} \mathrm{C} ;{ }^{1} \mathrm{H}-\mathrm{NMR}(600 \mathrm{MHz}$, DMSO-d6): $\delta 9.94(1 \mathrm{H}, \mathrm{s}), 7.38(1 \mathrm{H}, \mathrm{s}), 7.32-7.36$ $(2 \mathrm{H}, \mathrm{m}), 7.17(1 \mathrm{H}, \mathrm{t}), 6.97(1 \mathrm{H}, \mathrm{d}), 6.81-6.88(3 \mathrm{H}, \mathrm{m})$, $6.77(1 \mathrm{H}, \mathrm{d}), 3.85(2 \mathrm{H}, \mathrm{s}), 3.75(3 \mathrm{H}, \mathrm{s})$; EI-MS $(\mathrm{m} / \mathrm{z})$ $51,65,77,90,104,121,132,150,159,175,192,218$ $231,334,351,365(\mathrm{M})^{+}$; IR (KBr): v 3315, 2926, 1672, $1603,1551,1513,1464,1447,1384,1342,1296$, $1258,1195,1155,1126,1047,841,786,753,709$ $\mathrm{cm}^{-1}$.

\subsubsection{6-(4-hydroxybenzyl)-3-(4-methylphenyl)-7H-thi azolo[3,2-b]-1,2,4-triazin-7-one (4f)}

Yellow crystal; mp: $275-277^{\circ} \mathrm{C} ;{ }^{1} \mathrm{H}-\mathrm{NMR}(300 \mathrm{MHz}$, DMSO-d6): $\delta 9.25(1 \mathrm{H}, \mathrm{s}), 7.54(2 \mathrm{H}, \mathrm{d}, J=8.0 \mathrm{~Hz})$, $7.44(1 \mathrm{H}, \mathrm{s}), 7.25(2 \mathrm{H}, \mathrm{d}, J=8.0 \mathrm{~Hz}), 7.06(2 \mathrm{H}, \mathrm{d}, \mathrm{J}=$ $8.4 \mathrm{~Hz}), 6.76(2 \mathrm{H}, \mathrm{d}, J=8.4 \mathrm{~Hz}), 3.83(2 \mathrm{H}, \mathrm{s}), 2.35(3 \mathrm{H}$, s); ESI-MS (m/z): $350.0(\mathrm{M}+\mathrm{H})^{+}, 720.9(2 \mathrm{M}+\mathrm{Na})^{+}$; IR $(\mathrm{KBr})$ : v $3109,1643,1580,1515,1481,1414,1384$, $1363,1319,1265,1213,1172,1114,1042,876,816$, $790,765,751 \mathrm{~cm}^{-1}$.

\subsubsection{6-(4-methoxybenzyl)-3-(4-hydroxyphenyl)-7H-t hiazolo [3,2-b]-1,2,4-triazin-7-one (4g)}

White crystal; mp: $188-189^{\circ} \mathrm{C}$; ${ }^{1} \mathrm{H}-\mathrm{NMR}(600 \mathrm{MHz}$,
DMSO-d6): $\delta 10.0(1 \mathrm{H}, \mathrm{s}), 7.48(2 \mathrm{H}, \mathrm{d}, J=8.4 \mathrm{~Hz})$ $7.33(1 \mathrm{H}, \mathrm{s}), 7.21(2 \mathrm{H}, \mathrm{d}, J=8.4 \mathrm{~Hz}), 6.87(2 \mathrm{H}, \mathrm{d}, J=$ $8.4 \mathrm{~Hz}), 6.80(2 \mathrm{H}, \mathrm{d}, J=8.4 \mathrm{~Hz}), 3.91(2 \mathrm{H}, \mathrm{s}), 3.76(3 \mathrm{H}$, s); ESI-MS (m/z): $366.0(\mathrm{M}+\mathrm{H})^{+}, 752.8(2 \mathrm{M}+\mathrm{Na})^{+} ;$IR $(\mathrm{KBr}): v$ 3119, 1610, 1511, 1476, 1385, 1279, 1247 , $1176,1123,1029,838,752 \mathrm{~cm}^{-1}$.

\subsubsection{6-(4-methoxybenzyl)-3-(4-methoxyphenyl)-7H-t} hiazolo[3,2-b]-1,2,4-triazin-7-one (4h)

Yellow crystal; mp: $205-206{ }^{\circ} \mathrm{C}$; ${ }^{1} \mathrm{H}-\mathrm{NMR}(600 \mathrm{MHz}$, DMSO-d6): $\delta 7.57(2 \mathrm{H}, \mathrm{d}, J=8.4 \mathrm{~Hz}), 7.40(1 \mathrm{H}, \mathrm{s})$, $7.20(2 \mathrm{H}, \mathrm{d}, J=9.0 \mathrm{~Hz}), 6.97(2 \mathrm{H}, \mathrm{d}, J=9.0 \mathrm{~Hz}), 6.87$ $(2 \mathrm{H}, \mathrm{d}, J=8.4 \mathrm{~Hz}), 3.90(2 \mathrm{H}, \mathrm{s}), 3.81(3 \mathrm{H}, \mathrm{s}), 3.73(3 \mathrm{H}$, s); ESI-MS (m/z): $380.0(\mathrm{M}+\mathrm{H})^{+}, 780.9(2 \mathrm{M}+\mathrm{Na})^{+}$; IR $(\mathrm{KBr})$ : v 3107, 2931, 2833, 1636, 1580, 1513, 1481, $1417,1385,1359,1300,1253,1176,1115,1034,876$, $821,785,755 \mathrm{~cm}^{-1}$.

\subsection{Biology inhibition of AChE}

The inhibitory potency against $\mathrm{AChE}$ was evaluated by means of Ellman's test ${ }^{[14]}$. AChE stock solution was prepared by dissolving human AChE 0.5 unit in $100 \mathrm{mM}$ PBS buffer ( $\mathrm{pH}$ 7.4). Tested target compounds $(10 \mathrm{mM})$ were prepared in DMSO. The assay solution consisted of 100mMPBS buffer ( $\mathrm{pH} 7.4$ ) with the addition of $10 \mathrm{mM} 5,5^{\prime}$-dithiobis (2-nitrobenzoic acid) (DTNB, Ellman's reagent), AChE (5 mL), drug $(10 \mathrm{~mL})$, and $12.5 \mathrm{mM}$ acetylthiocholine iodide (ATCh) water solution. The final assay volume was $900 \mathrm{~mL}$. Incubate the reaction at $37{ }^{\circ} \mathrm{C}$ for $15 \mathrm{~min}$ with continuous gentle shake. Add $50 \mathrm{~mL}$ ATCh and $50 \mathrm{~mL}$ DTNB. Incubate at $37{ }^{\circ} \mathrm{C}$ for about $20 \mathrm{~min}$ with continuously gentle shake. Wait until the yellow color was developed and measure it at $412 \mathrm{~nm}$. Calculate the specific inhibition rates.

\subsection{Docking studies}

To disclose a possible binding mode of compounds with hAChE enzyme's binding pockets, the docking simulation was performed through using the available crystallographic structure of enzyme (PDB ID: 4EY7) and AUTODOCK 4.0 (The Scripps Research Institute, LA Jolla, CA, USA). To obtain the better results from docking protocols, water molecules and other ligand (NAG) were excluded. The polar hydrogen atoms of the enzyme were added, the non-polar hydrogen atoms were merged, and Gasteiger charges were assigned. For all ligands, the non-polar hydrogen atoms were merged and the Gasteiger charges were assigned. The grid box dimensions were $60 \times 60 \times 60 \AA$ around the active site, and the grid spacing was set to $0.375 \AA$. Docking was performed through using the empirical free energy function together with the Lamarckian genetic algorithm (LGA). The LGA protocol was applied to 150 individuals, while 250000 energy evaluations were used for the 20 LGA runs. In addition, the maximum number of evaluations was set to 27000 . In this study, the co-crystal natural substrate, donepezil, was taken out of the active site and docked 


\section{MATEC Web of Conferences}

again, and it was used as the template for molecular alignment. The cluster analyses were computed with a cluster tolerance by< $1.5 \AA$ in positional root-mean-square deviation. The Discovery Studio (DS) Visualizer 2.5 software was used for visualization of protein-ligand interactions.

\section{CONCLUSION}

7H-thiazolo[3,2-b]-1,2,4-triazin-7-one derivatives were designed and synthesized as dual binding site inhibitors of AChE. We have found a practical and green synthesis procedure for preparing 7H-thiazolo[3,2-b][1,2,4]triazin-7-ones by one-pot, three-component condensation of arylpyruvic acids, thiosemicarbazide, and 2-bromoacetophenones in the presence of ionic liquid $[\mathrm{Hnhm}] \mathrm{HSO}_{4}$. The main advantages of higher yields lack organic solvent and the easy synthetic procedure. All these derivatives have been investigated for their inhibitory activity in vitro through using Ellman's method. The results revealed that most compounds displayed moderate inhibitory activity. Among them, compounds $4 \mathrm{~b}, 4 \mathrm{e} 4 \mathrm{f}$, and $4 \mathrm{~g}$ bearing hydroxy group exert the better potency. Molecular docking results revealed that $4 \mathrm{~b}, 4 \mathrm{e} 4 \mathrm{f}$, and $4 \mathrm{~g}$ might be able to form hydrogen bond with $\mathrm{AChE}$ receptor. These studies suggest that $7 \mathrm{H}$-thiazolo [3,2-b]-1,2,4-triazin-7-one derivatives may be a promising structural template for the development of novel AChE inhibitors in managing amnesic disorders including $\mathrm{AD}$.

\section{ACKNOWLEDGEMENT}

This paper is sponsored by the Youth Foundation of Hebei Educational Committee (GN: QN2014311).

\section{REFERENCES}

[1] Van, G.J. et al. 2000. The art of writing a scientific article. J Sci Commun. 163: 51-9.

[2] Shadpour, M. \& Mohammad, D. 2012. Ionic Liquids as Green Solvents: Progress and Prospects. Green Solvents II. 1-32.
[3] Xu, H.N. et al. 2012. Design, synthesis characterization and in vitro biological activity of a series of 3-aryl-6-(bromoarylmethyl)-7Hthiazolo[3,2-b]-1,2,4-tria zin-7-one derivatives as the novel acetylcholinesterase inhibitors. Chinese Chemical Letters. 23: 765-768.

[4] Brookmeyer, R. et al. 2007. Forecasting the global burden of Alzheimer's disease. Alzheimers Dement. 3: 186-191.

[5] Jin, Z. et al. 2010. Synthesis and Biological Evaluation of 3,6-diaryl-7H-thiazolo[3,2-b][1,2,4]triazin-7-one Derivatives as Acetylcholinesterase Inhibitors. Archives of Pharmacal Research. 33(10): 1641-1649.

[6] Liu S.J. et al. 2013. Design, synthesis and Biological Evaluation of $7 \mathrm{H}$-thiazolo[3,2-b][1,2,4]triazin-7-one Derivatives as dual binding site Acetylcholinesterase Inhibitors. Hyterocycles. 87(12): 2607-2614.

[7] Liu S.J. et al. 2009. Design, synthesis, and biological evaluation of $7 \mathrm{H}$ thiazolo[3,2b]-1,2,4-triazin-7-one derivatives as novel acetylcholinesterase inhibitors. ARKIVOC. (10): 333-348.

[8] Tang, H. et al. 2007. Derivatives of oxoisoaporphine alkaloids: A novel class of selective acetylcholinesterase inhibitors. Bioorganic Medicinal Chemistry Letters. 17(13): 3765-3768.

[9] Stahl, S.M. et al. 2000. The new cholinesterase inhibitors for Alzheimer's disease, part 2: illustrating their mechanisms of action. The Journal of Clinical Psychiatry. 61(11): 813-814.

[10] Sussman, J.L. et al. 1991. Atomic structure of acetylcholinesterase from Torpedo californica: a prototypic acetylcholine-binding protein. Science. 253(5022): 872-879.

[11] Petra K. et al. 2003. Synthesis, Biological Activity, and Docking Studies of New Acetylcholinesterase Inhibitors of the Bispyridinium Type. Archiv der Pharmazie. 336:523-528.

[12]Asaad, K. et al. 2004. Kinetics and structure-activity relationship studies on pregnane-type steroidal alkaloids that inhibit cholinesterases. Bioorganic \& Medicinal Chemistry. 12(9): 1995-2003.

[13] Kryger, G. et al. 2000. Structures of recombinant native and E202Q mutant human acetylcholinesterase complexed with the snake-venom toxin fasciculin-II. Acta crystallographica Section D. 56: 1385-1394.

[14]George, L. et al. 1961. A new and rapid colorimetric determination of acetylcholinesterase activity. Biochemical Pharmacology. 7(2): 88-90. 